\title{
IMPLEMENTASI MASTER STRATEGI DALAM MENCIPTAKAN NILAI PUBLIK PADA PDAM TKR KABUPATEN TANGERANG
}

\author{
Arsid 1, Ida Widianingsih 2, Heru Nurasa ${ }^{3}$, Entang Adhy Muhtar 4 \\ 1 Program Pascasarjana Universitas Padjadjaran \\ 2 Pusat Studi Desentralisasi dan Pembangunan Partisipatif \\ 3, 4 Departemen Administrasi Publik, FISIP Universitas Padjadjaran \\ Email: arsidtangsel2017@gmail.com
}

Article Histori:

Submited: 30/09/2018

Review: 02/10/2018

Editing: 25/04/2019

Publish: 29/04/2019

\begin{abstract}
The main problem faced by PDAM TKR Tangerang Regency is the low coverage of drinking water services for domestic customers or the community. Whereas services for non-domestic customers such as companies and apartments, Tangerang TKR PDAM is considered to have provided good and optimal services. The service provided by the Tangerang Regency TKR PDAM is done unevenly. This problem can be found in the difference in service quality between domestic and non-domestic consumers. This study focuses on the problem of less than optimal service to domestic customers by the Tangerang TKR PDAM. Public value theory by Mark Moore becomes the basic theory used to measure the success of a company in providing good and optimal service to the community. Company achievements are assessed in terms of service, results and trust. The strategy needed to realize this public value is the Strategy Master initiated by Higgins which includes corporate strategy, business strategy, functional strategy and enterprise strategy. This study recommends that to realize a good and optimal Public Value, Tangerang Regency TKR PDAM is deemed necessary to use the Strategy Master in its entirety and comprehensively in an effort to serve the community as domestic customers.
\end{abstract}

Keyword: Service Strategy, Master Strategy, Public Value

\section{PENDAHULUAN}

Setiap badan usaha yang dikelola oleh pemerintah baik pusat maupun daerah bertanggung jawab untuk memberikan pelayanan yang baik dan optimal kepada publik atau masyarakat. Pemerintah sebagai penyelenggara pelayanan publik harus melaksanakan serangkaian kegiatan dalam rangka pemenuhan kebutuhan pelayanan sesuai dengan peraturan perundang-undangan bagi setiap warga negara baik itu berupa barang, jasa, atau pelayanan administratif. Penyelenggara pelayanan publik harus senantiasa mempertimbangkan aspek proporsionalitas dan kebutuhan masyarakat dengan berpegang pada prinsip keadilan, supaya dalam prakteknya tidak menimbulkan 
sikap diskriminasi kepada masyarakat secara umum.

Salah satu Badan Usaha Milik Daerah (BUMD) yang memberikan pelayanan kepada masyarakat atas kebutuhan air minum adalah Perusahaan Daerah Air Minum (PDAM) Tirta Kerta Raharja (TKR) Kabupaten Tangerang. PDAM TKR Kabupaten Tangerang ini memiliki tujuh tujuan, yaitu pertama menyediakan kebutuhan air minum bagi masyarakat secara berkesinambungan, melalui pelayanan prima; kedua memproduksi air minum sesuai dengan standar yang berlaku; ketiga menyelenggarakan pengelolaan air minum dengan menerapkan teknologi yang tepat; keempat memberikan kontribusi yang optimal bagi Pendapatan Asli Daerah (PAD); kelima memberikan pelayanan air minum dengan tarif yang terjangkau; keenam meningkatkan kualitas SDM agar mampu berkreasi dan berinovasi secara profesional; dan ketujuh menjalankan aktivitas usaha dengan selalu menjaga keseimbangan lingkungan.

Sistem produksi dan distribusi air minum di PDAM TKR Kabupaten Tangerang dilakukan untuk memenuhi kebutuhan air minum pelanggan secara optimal yang meliputi aspek kualitas, kuantitas, kontinuitas, dan tekanan. PDAM TKR Kabupaten Tangerang secara dominan menggunakan sumber air baku yang berasal dari sungai Cisadane, kemudian ditambah dari Sungai Cidurian dan Cipasilian. Mengacu pada Sertifikat Izin Penggunaan dan Pemanfaatan Air Permukaan (SIPPA), volume air yang diijinkan untuk digunakan sebesar 4.860 liter/detik. Hingga tahun 2015, volume air baku yang sudah digunakan baru mencapai angka 4860 liter/detik.

Pada tahun 2014, hasil olahan produksi air baku tersebut telah berhasil dijual kepada pelanggan yaitu lebih dari 153 juta $\mathrm{m}^{3}$. Itu artinya, dari proses produksi sampai dengan penjualan kepada pelanggan dapat dikategorikan baik. Namun yang jadi permasalahannya adalah terjadi ketimpangan pada sistem pelayanan atau pendistribusian air minum kepada pelanggan PDAM TKR Kabupaten Tangerang.

Air minum yang diproduksi oleh PDAM TKR Kabupaten Tangerang didistribusikan kepada dua pelanggan, yaitu pertama, pelanggan domestik atau masyarakat umum dan kedua, pelanggan khusus seperti kantor-kantor pemerintahan, apartemen, hotel, dan perusahaan-perusahaan swasta lainnya.

Dengan adanya dua pendistribusian air minum yang dilakukan oleh PDAM TKR Kabupaten Tangerang tersebut, menimbulkan permasalahan di lapangan yang dihadapi oleh PDAM TKR Kabupaten Tangerang, yang mana tidak optimalnya pengelolaan air minum dan pendistribusiannya, hal ini terlihat dalam hal pendistribusian air minum bagi masyarakat di wilayah Kabupaten Tangerang (domestik), yang mana di wilayah Kabupaten Tangerang dengan penduduk sebesar 3.157.780 jiwa, hanya dapat melayani air minum kepada masyarakat pada Tahun 2014 sebesar 29,39\% dengan jumlah pelanggan 124.945 
pelanggan. Kemudian pada tahun 2015 sebesar 33,66\% atau dengan jumlah pelanggan 130.000 pelanggan. Sedangkan pada tahun 2016 sebesar 30,17\% dengan jumlah pelanggan sebesar 135.314 pelanggan. Hal tersebut dapat terlihat di dalam grafik sebgai berikut:

\section{Grafik 1:}

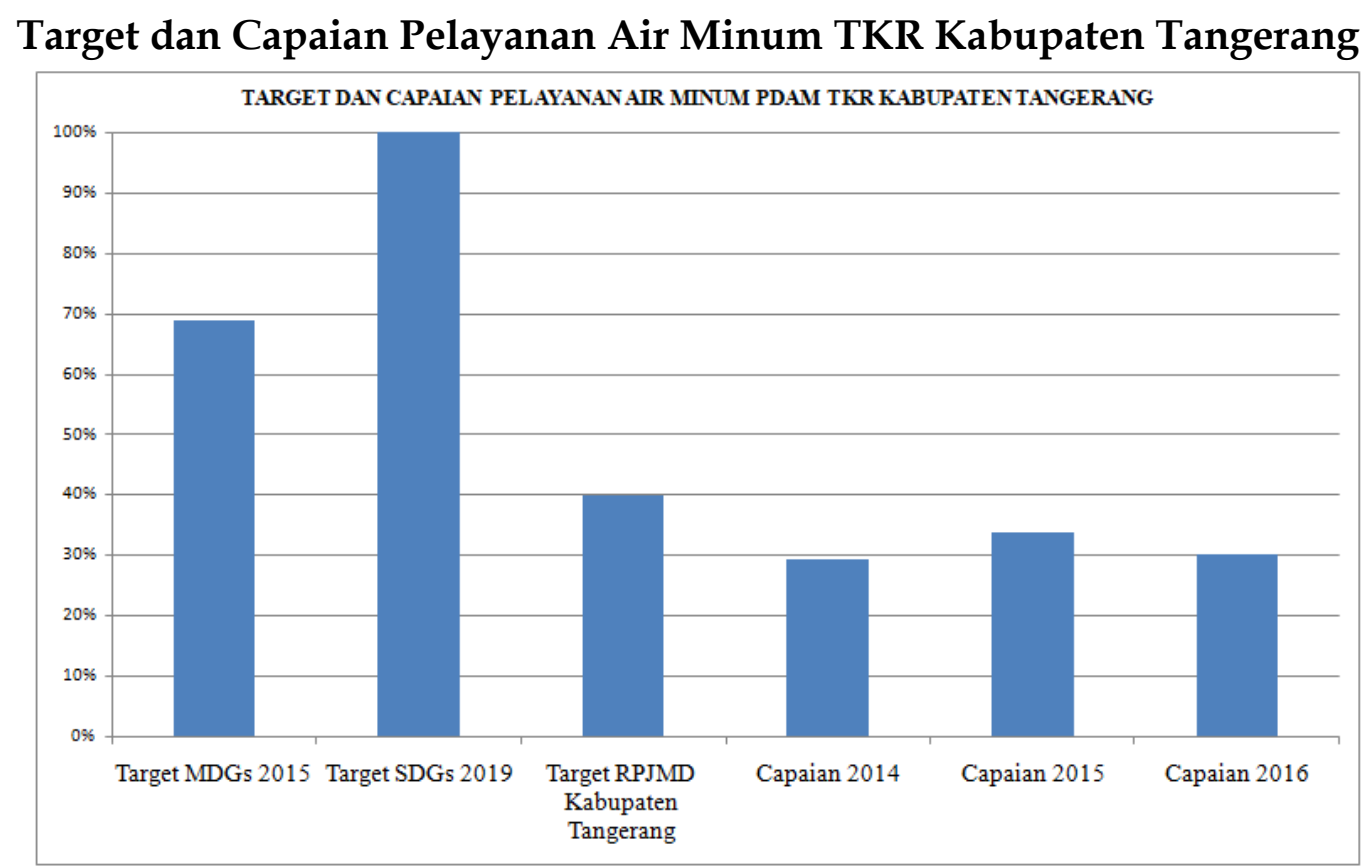

Sumber: PDAM TKR Kabupaten Tangerang 2015

Mengacu pada Target Millenium Development Goals (MDGs) 2015 bahwa Pemerintah Indonesia menetapkan pelayanan ketersediaan air bersih sebesar $68,87 \%$. Target tersebut sebenarnya sudah tercapai yaitu sebesar 70,97\%. Kemudian, guna melanjutkan keberhasilan pencapaian target Millennium Development Goals (MDGs) 2015 tersebut, pemerintah telah mencanangkan pencapaian Sustainable Development Goals (SDGs) dalam RPJMN 2015-2019 sebagai prioritas pembangunan yaitu sebesar 100\%, yang di dalamnya menghendaki agar akses universal air minum aman memenuhi $4 \mathrm{~K}$ yaitu kuantitas, kualitas, kontinuitas, dan keterjangkauan.
Guna mendukung target yang ditetapkan oleh pemerintah pusat baik mengacu pada MDGs 2015 ataupun SDGs 2019, pemerintah Kabupaten Tangerang melalui RPJMD menetapkan target capaian pelayanan air minum ke masyarakat sebesar 40\%. Realisasinya, pada tahun 2014 hanya mencapai target $29,39 \%$, pada tahun 2015 mencapai target 33,66 \% dan pada tahun 2016 mencapai target 30,17\%. Tentunya, capaian angka tersebut masih jauh dari target pemerintah daerah serta pemerintah pusat dalam rangka memenuhi standar pelayanan yang ditargetkan MDGs maupun SDGs.

Oleh sebab itu, peneliti menilai bahwa pelayanan air minum yang dilakukan oleh 
PDAM TKR Kabupaten Tangerang dinilai belum optimal dalam memberikan pelayanan kebututuhan Air Minum Domestik bagi Masyarakat Kabupaten Tangerang, padahal PDAM TKR Kabupaten Tangerang merupakan salah satu dari sekian banyaknya PDAM yang ada di Indonesia sebagai PDAM dengan predikat sehat.

Berangkat dari masalah pokok ini, maka dapat dikemukakan sebuah rumusan masalah penelitian sebagai berikut: Bagaimana Strategi Pelayanan Air Minum PDAM TKR Kabupaten Tangerang Studi dalam Melayani Kelompok Konsumen Domestik? Adapun tujuan dari penelitian ini adalah untuk menghasilkan strategi pelayanan air minum yang mampu menghasilkan konsep baru tentang strategi pelayanan air minum pada Perusahaan Daerah Air Minum (PDAM) Tirta Kerta Raharja Kabupaten Tangerang.

Secara akademik, penelitian ini diharapkan dapat memberikan informasi ilmiah yang bermanfaat dalam strategi pelayanan, khususnya yang berkaitan strategi pelayanan yang dilakukan oleh Perusahaan Publik serta dapat dijadikan masukan bagi para peneliti yang ingin mengembangkan lebih lanjut mengenai konsep strategi pelayanan air minum pada Perusahaan Daerah Air Minum. Sedangkan secara praktis, hasil dari penelitian yang diperoleh, kiranya dapat dijadikan bahan masukan bagi Pemerintah Daerah Kabupaten Tangerang dalam mengelola Badan Usaha Milik Daerah, khususnya Perusahaan Daerah Air Minum (PDAM) Tirta Kerta Raharja Kabupaten Tangerang serta menjadi bahan masukan bagi manajemen Perusahaan Daerah Air Minum (PDAM) Tirta Kerta Raharja Kabupaten Tangerang dalam melakukan perbaikanperbaikan guna mencapai bentuk pelayanan yang baik dan optimal.

\section{TELAAH TEORITIS}

\section{Konsep Pelayanan Publik}

Secara kebahasaan, pelayanan dapat dimaknai sebagai aktivitas membantu menyiapkan atau mengurus segala sesuatu apa yang diperlukan orang lain. Pelayanan juga dapat diartikan sebagai prihal melayani, servis jasa dan kemudahan yang diberikan sehubungan dengan jual beli barang atau jasa (Depdikbud, 1995: 571). Dalam pengertian yang lebih jauh, Sianipar memberikan dua pemaknaan mengenai konsep pelayanan, yaitu pertama, cara melayani, menyiapkan atau menjamin keperluan seseorang atau kelompok orang, dan kedua, meladeni atau membantu mengurus keperluan atau kebutuhan seseorang sejak diajukan permintaan sampai penyampaian atau penyerahannnya (J.P.G Sianipar, 1998: 4).

Pelayanan sepadan dengan kata service dalam bahasa Inggris, yaitu serangkaian kegiatan atau proses yang saling memenuhi kebutuhan antara penerima dan pemberi pelayanan. Berikut merupakan beberapa definisi pelayanan yang dikemukakan oleh beberapa ahli, yaitu sebagai berikut:

1. The Lian Gie menyatakan bahwa pelayanan mencakup pelayanan bagi masyarakat atau kegiatan dari organisasi yang dilakukan untuk 
mengamalkan dan mengabdikan diri kepada masyarakat (The Lian Gie, 1997: 23).

2. Gronroos menyatakan bahwa pelayanan merupakan aktivitas atau serangkaian aktivitas yang bersifat tidak kasat mata (tidak dapat diraba) yang terjadi sebagai akibat adanya interaksi antara konsumen dengan karyawan atau hal-hal yang disediakan oleh perusahaan pemberi pelayanan dimaksudkan untuk memecahkan permasalahan konsumen atau pelanggan (Ratminto \& Atik, 2004: 3).

3. A.S Moenir mengartikan pelayanan sebagai kegiatan yang dilakukan oleh seseorang atau sekelompok orang dengan landasan tertentu yang tingkat pemuasannya hanya dapat dirasakan oleh orang yang melayani atau yang dilayani, bergantung pada kemampuan penyedia jasa dalam memenuhi harapan pengguna jasa pelayanan (A.S. Moenir, 2002: 16).

Dari beberapa uraian definisi mengenai konsep pelayanan di atas, maka dapat ditarik satu kesimpulan bahwa pelayanan pada hakikatnya merupakan satu proses kegiatan antara si pemberi pelayanan dengan si penerima pelayanan baik perorangan maupun kelompok dengan dasar atau prinsip-prinsip tertentu demi terwujudnya kebutuhan dan kepuasan antara kedua belah pihak.

Beberapa definisi pelayanan di atas sejatinya mengarah pada konsep pelayanan publik yang merupakan pemberian layanan (melayani) keperluan orang atau masyarakat yang mempunyai kepentingan pada organisasi atau institusi sesuai dengan aturan pokok dan tata cara yang telah ditetapkan (Zaenal Mukarram \& Muhibudin Wijaya, 2016: 41).

Secara jelas, berikut merupakan beberapa pengertian pelayanan publik yang dikemukakan oleh beberapa ahli, yaitu:

1. Pelayanan publik (public service) adalah pelayanan atau pemberian terhadap masyarakat berupa penggunaan fasilitas umum, baik jasa maupun non-jasa, yang dilakukan oleh organisasi publik, yaitu pemerintah (Ahmad Ainur Rohmah., dkk, 2010: 3).

2. Pelayanan publik adalah setiap kegiatan yang dilakukan oleh pemerintah terhadap sejumlah manusia yang memiliki setiap kegiatan yang menguntungkan dalam kumpulan atau kesatuan dan menawarkan kepuasan meskipun hasilnya tidak terikat pada suatu produk secara fisik (Sinambela, 2008: 5).

Ada empat unsur penting dalam proses pelayanan publik, pertama penyedia layanan, yaitu pihak yang dapat memberikan suatu layanan tertentu kepada konsumen, baik berupa layanan dalam bentuk penyediaan dan penyerahan barang (goods) atau jasa-jasa (services). Kedua penerima layanan, yaitu mereka yang disebut sebagai konsumen (costumeri) yang menerima berbagai layanan dari penyedia layanan. Ketiga, jenis layanan, yaitu layanan yang dapat diberikan oleh penyedia layanan kepada pihak yang membutuhkan layanan. Dan keempat, kepuasan pelanggan, dalam memberikan layanan penyedia layanan harus mengacu pada tujuan utama dari pelayanan tersebut yaitu kepuasan pelanggan yang berkaitan 
dengan standar kualitas barang atau jasa (Bharata, 2004: 11).

Pelayanan publik yang dilakukan oleh pemerintah pusat atau daerah bertugas untuk memberikan pelayanan secara cumacuma atau dengan biaya yang minimal/terjangkau/murah kepada masyarakat umum tanpa membedabedakan sehingga kelompok masyarakat yang paling tidak mampu pun dapat mengkases atau merasakan dari manfaat pelayanan tersebut (Nugroho, 2004: 75).

Mengacu pada Surat Keputusan Menteri Pemberdayaan Aparatur Negara nomor 63 tahun 2004 tentang Pedoman Umum Penyelenggaraan Pelayanan Publik disebutkan bahwa hakikat pelayanan publik adalah pemberian pelayanan prima kepda masyarakat yang merupakan perwujudan kewajiban aparatur pemerintah sebagai abdi masyarakat. Adapun asas dari pelayanan publik harus berdasarkan atas enam hal, yaitu:

1. Transparansi, yaitu bersifat terbuka, mudah dan dapat diakses oleh semua pihak yang membutuhkan dan desediakan secara memadai serta mudah dimengerti.

2. Akuntabilitas, yaitu dapat dipertanggungjawabkan sesuai dengan ketentuan peraturan perundangundangan.

3. Kondisional, yaitu sesuai dengan kondisi dan kemampuan pemberi dan penerima pelayanan dengan tetap berpegang pada efesiensi dan efektifitas.

4. Partisipatif, yaitu mendorong peran serta masyarakat dalam penyelenggaraan pelayanan publik dengan memperhatikan aspirasi, kebutuhan dan harapan masyarakat.

5. Kesamaan hak, yaitu tidak diskriminatif dalam arti tidak membedakan suku, ras, agama, gender, dan status ekonomi.

6. Keseimbangan hak dan kewajiban, yaitu pemberi dan penerima pelayanan publik harus memenuhi hak dan kewajiban masing-masing pihak.

Dalam surat keputusan tersebut juga disebutkan prinsip-prinsip dari pelayanan di sektor publik yaitu:

1. Prinsip kesederhanaan, yaitu prosedur pelayanan publik tidak berbelit-belit, mudah dipahami dan mudah untuk dilaksanakan.

2. Prinsip kejelasan, yaitu meliputi kejelasan dalam wilayan persyaratan teknis dan administrasi pelayanan publik; unit kerja/pejabat yang berwenang dan bertanggungjawab dalam meberikan pelayanan dan penyelesaian

keluhan/persoalan/sengketa dalam pelaksanaan pelayanan publik; dan rincian biaya pelayanan publik dan tatacara pembayaran.

3. Prinsip kepastian waktu, yaitu pelaksanaan pelayanan publik dapat diselesaikan dalam kurun waktu yang telah ditentukan.

4. Prinsip akurasi, yaitu produk pelayanan publik diterima dengan benar, tepat, dan sah.

5. Prinsip keamanan, yaitu proses dan produk pelayanan publik memberikan rasa aman dan kepastian hukum. 
6. Prinsip tanggung jawab, yaitu pimpinan penyelenggara pelayanan publik atau pejabat yang ditunjuk bertanggungjawab atas penyelenggaraan pelayanan dan penyelesaian keluhan/persoalan dalam pelaksanaan pelayanan publik.

7. Prinsip kelengkapan sarana dan prasarana, yaitu tersedianya sarana dan prasarana kerja, peralatan kerja dan pendukung lainnya yang memadai termasuk penyediaan sarana teknologi telekomunikasi dan informatika (telematika).

8. Prinsip kemudahan akses, yaitu tempat dan lokasi serta sarana pelayanan yang memadai, mudah dijangkau oleh masyarakat, dan dapat memanfaatkan teknologi telekomunikasi dan informatika.

9. Prinsip kedisiplinan, kosopanan, dan keramahan, yaitu pemberi pelayanan harus bersikap disiplin, sopan, dan santun, ramah, serta memberikan pelayanan yang ikhlas.

10. Prinsip kenyamanan, yaitu lingkungnan harus tertib, teratur, disediakan ruang tunggu yang nyaman, bersih, rapi, lingkungan yang indah dan sehat serta dilengkapi dengan fasilitas pendukung pelayanan seperti parkir, toilet, tempat ibadah, dan lain-lain.

Setidaknya pemerintah memberikan pelayanan publik kepada masyarakat meliputi tiga sektor, pertama sektor pelayanan administratif, yaitu pelayanan yang menghasilkan berbagai produk dokumen resmi yang diperlukan oleh masyarakat, misalnya starus kewarganegaraan,

kepemimpinan, penguasaan suatu barang, sertifikat dan dokumen-dokumen lainnya semisal Kartu Tanda Penduduk (KTP), Akta Kelahiran, Sertipikat Tanah, Akta Pernikahan, Parpor, BPKB, Surat Izin Mengemudi (SIM), Izin Mendirikan Bangunan (IMB), dan lain sebagainya. Kedua, sektor pelayanan barang, yaitu pelayanan yang menghasilkan berbagai bentuk atau jenis barang yang digunajan oleh publik misalnya penyediaan air bersih layak pakai dan layak minum, tenaga listrik, jaringan telepon dan lain sebagainya. Dan ketiga, sektor pelayanan jasa, yaitu pelayanan yang menghasilkan berbagai bentuk jasa yang diperlukan oleh masyarakat misalnya pendidikan, kesehatan, sarana transportasi dan lain sebagainya.

Strategi pelayanan publik yang dilakukan oleh instansi pemerintah baik pusat maupun daerah sejatinya harus berorientasi pada pemenuhan atas ragam kebutuhan mendasar masyarakat yang meliputi pelayanan administasi, pelayanan barang, ataupun pelayanan jasa yang dapat diakses secara mudah dengan biaya yang terjangkau dan dapat dirasakan nilai manfaat sebesar-besarnya.

\section{KONSEP MASTER STRATEGI}

Strategi pada dasarnya merupakan suatu seni dalam hal menggunakan kemampuan, kecakapan dan sumber daya suatu organisasi untuk mencapai apa yang hendak ditujunya dengan cara-cara yang efektif serta disesuaikan dengan lingkungan dimana ia berada. Higgins (1985) menjelaskan ada empat strategi yang bisa digunakan oleh organisasi atau instansi tertentu dalam menjalankan 
aktivitasnya. Keempat strategi tersebut ialah enterprise strategy, corporate strategy, bussines strategy, dan funcional strategy. Secara lazim, kemudian ia menyebut keempat strategi tersebut dengan istilah master strategy (Salusu, 1996:1001).

Pertama, Corporate Strategy. Strategi ini berkaitan dengan misi organisasi, sehingga sering disebut Grand Strategy yang meliputi bidang yang digeluti oleh suatu organisasi. Pertanyaan apa yang menjadi bisnis atau urusan kita dan bagaimana kita mengendalikan bisnis itu, tidak semata-mata untuk dijawab oleh organisasi bisnis, tetapi juga oleh setiap organisasi pemerintahan dan organisasi nonprofit. Apakah misi universitas yang utama? Apakah misi yayasan ini, yayasan itu, apakah misi lembaga ini, lembaga itu? Apakah misi utama direktorat jenderal ini, direktorat jenderal itu? Apakah misi badan ini, badan itu? Begitu seterusnya. Jawaban terhadap pertanyaan-pertanyaan itu sangat penting dan kalau keliru dijawab bisa fatal. Misalnya, kalau jawaban terhadap misi universitas ialah terjun kedalam dunia bisnis agar menjadi kaya maka akibatnya bisa menjadi buruk, baik terhadap anak didiknya, terhadap pemerintah, maupun terhadap bangsa dan negaranya. Bagaimana misi itu dijalankan juga penting. Ini memerlukan keputusan-keputusan stratejik dan perencanaan stratejik yang selayaknya juga disiapkan oleh setiap organisasi.

Kedua, Business Strategy. Strategi pada tingkat ini menjabarkan bagaimana merebut pasaran di tengah masyarakat. Bagaimana menempatkan organisasi di hati para penguasa, para pengusaha, para donor dan sebagainya. Semua itu dimaksudkan untuk dapat memperoleh keuntungankeuntungan stratejik yang sekaligus mampu menunjang berkembangnya organisasi ke tingkat yang lebih baik. Dalam istilah bisnis,, strategi ini memusatkan perhatian pada keunggulan kompetitif yang untuk kalangan nonprofit lebih disukai menggunakan istilah keunggulan komparatif.

Ketiga, Functional Strategy. Strategi ini merupakan strategi pendukung dan untuk menunjang suksesnya strategi lain. Ada tiga jenis strategi fungsional yaitu: 1) Strategi fungsional ekonomi yaitu mencakup fungsi-fungsi yang memungkinkan organisasi hidup sebagai satu kesatuan ekonomi yang sehat, antara lain yang berkaitan dengan keuangan, pemasaran, sumber daya, penelitian dan pengembangan; 2) Strategi fungsional manajemen, mencakup fungsi-fungsi manajemen yaitu planning, organizing, implementating, controlling, staffing, leading, motivating, communicating, decision making, representing, dan integrating; dan 3) Strategi isu stratejik, fungsi utamanya ialah mengontrol lingkungan, baik situasi lingkungan yang sudah diketahui maupun situasi yang belum diketahui atau yang selalu berubah. Tingkat-tingkat strategi itu merupakan kesatuan yang bulat dan menjadi isyarat bagi setiap pengambil keputusan tertinggi bahwa mengelola organisasi tidak boleh dilihat dari sudut kerapian administratif semata, tetapi juga hendaknya memperhitungkan soal kesehatan organisasi dari sudut ekonomi. 
Dan keempat Enterprise Strategy. Strategi ini berkaitan dengan respons masyarakat. Setiap organisasi mempunyai hubungan dengan masyarakat. Masyarakat adalah kelompok yang berada di luar organisasi yang tidak dapat dikontrol. Di dalam masyarakat yang tidak terkendali itu, ada pemerintah dan berbagai kelompok lain seperti kelompok penekan, kelompok politik dan kelompok sosial lainnya. Jadi dalam strategi enterprise terlihat relasi antara organisasi dan masyarakat luar, sejauh interaksi itu akan dilakukan sehingga dapat menguntungkan organisasi. Strategi itu juga menampakkan bahwa organisasi sungguh-sungguh bekerja dan berusaha untuk memberi pelayanan yang baik terhadap tuntutan dan kebutuhan masyarakat. Respon terhadap keinginan masyarakat perlu diberi perhatian dengan pertimbangan-pertimbangan etis.

\section{Menciptakan Nilai Publik}

Untuk menciptakan nilai publik, para penyelenggara pelayanan publik perlu memahami tiga komponen utama trilogi strategi. Ketiga komponen utama pelayanan publik tersebut merupakan fitur pembeda antara pelayanan publik dengan pelayanan yang diberikan oleh sektor swasta. Pertama adalah pelayanan (services), merupakan azas utama pelayanan publik melalui pelayanan yang bermutu untuk memenuhi kebutuhan masyarakat dengan prinsip-prinsip yang benar seperti keterbukaan, keadilan dan kepastian hukum. Kedua, manfaat (outcomes) yaitu seperti pengurangan kemiskinan, kesehatan publik, ketertiban dan kenyamanan kota. Manfaat yang dihasilkan oleh pelayanan publik kental dengan kepentingan publik yang bukan mencari keuntungan sehingga akan terjadi ambigu bila pelayanan publik di-drive oleh prinsipprinsip yang dipakai oleh korporasi, karena manfaat layanan publik lebih mengutamakan manfaat sosial, lingkungan hidup yang berkelanjutan (sustainable) serta ketertiban umum. Dan ketiga adalah kepercayaan (trust), setiap organisasi pelayanan publik dibentuk untuk menjaga dan meningkatkan kepercayaan masyarakat terhadap pemerintah dengan cara partisipasi dan keterlibatan yang lebih nyata.

\section{Gambar 1: Nilai Publik Mark Moore}

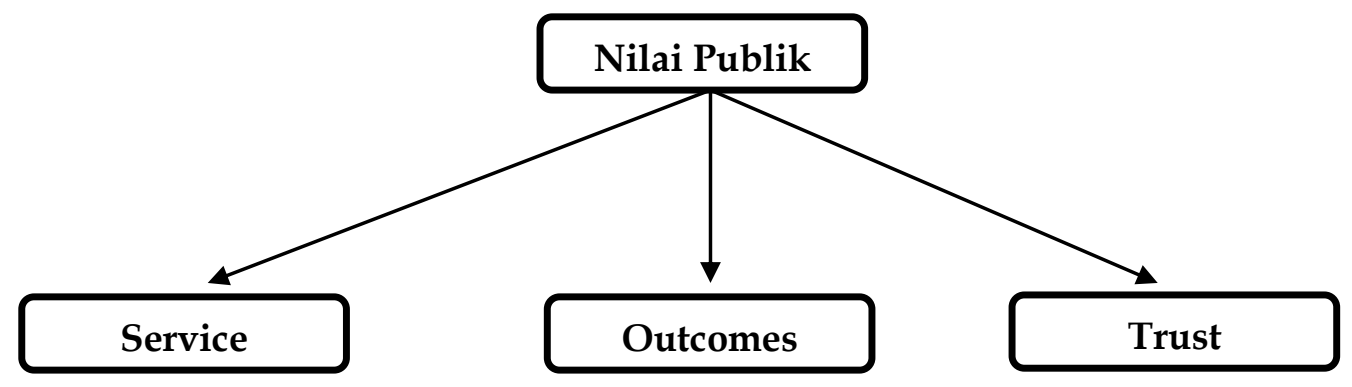

Sumber: Moore (1995)

Pada dasarnya, penciptaan nilai publik dibangun dari suatu strategi 
organisasional yakni trilogi strategi (a strategic triangle) yang dipopulerkan oleh Mark Moore. Menurut konsep ini, tugas penyelenggara pelayanan publik dianalogikan hampir sama dengan tugas manajer sektor swasta. Sebagaimana para manajer sektor swasta menciptakan nilai ekonomis bagi shareholders atau para pemilik modal, para penyelenggara pelayanan publik diharapkan menciptakan nilai publik dalam program-program yang dijalankan. Spano berpendapat bahwa nilai publik dapat tercapai bilamana layanan yang dihasilkan oleh organisasi sektor publik memenuhi kebutuhan penduduk, sehingga semakin tinggi kepuasan masyarakat, semakin besar nilai publik yang diciptakan (Spano, 2009: 328).

Sedangkan menurut Mark Moore bahwa organisasi publik dikatakan telah menciptakan nilai publik apabila hasil manfaat yang diterima oleh masyakat lebih besar daripada biaya yang dikeluarkan termasuk didalamnya penggunaan aspek hukum yang memaksa pengguna layanan untuk mematuhi ketentuan perundangundangan (Moore, 1995). Sedangkan O'Flynn (2007) mendeskripsikan nilai publik sebagai konstruk mutli-dimensi yang merupakan cerminan dari preferensi yang secara kolektif diekspresikan secara politis yang dikonsumsi oleh warga negara - yang diciptakan tidak hanya melalui hasil tetapi juga melalui proses yang dapat menghasilkan kepercayaan atau keadilan.

\section{METODE}

Penelitian ini, menggunakan pendekatan kualitatif. Data yang dikumpulkan melalui penelitian ini adalah data yang sesuai dengan fokus penelitian, yaitu hal-hal yang menyebabakan tidak optimalnya pelayanan yang diberikan kepada masyarakat Kabupaten Tangerang sebagai pelanggan domestik. Data primer dalam penelitian ini diperoleh dalam bentuk kata-kata atau ucapan lisan dan prilaku dari subjek (informan) yang berkaitan dengan aspek-aspek kualitas pelayanan di PDAM TKR Kabupaten Tangerang. Sedangkan data sekunder yaitu berupa tulisan-tulisan, rekaman, gambar/foto, peta, grafik yang berhubungan dengan aspek kualitas pelayanan PDAM TKR Kabupaten Tangerang. Di samping itu juga data sekunder ini berupa laporan-laporan kerja, dan penelitan-penelitian khususnya yang berhubungan dengan pelayanan air bersih PDAM TKR Kabupaten Tangerang. Informan untuk penelitian ini terdiri atas dua jenis, yaitu internal dan eksternal, dimana masing-masing berjumlah enam orang untuk jenis informan internal dan sebelas orang untuk jenis informan eksternal. Total keseluruhan adalah dua puluh tiga orang informan.

Penyajian data dimuat dalam bentuk naratif setelah diidentifikasi, dideskripsikan, dan dianalisis, meskipun masih berupa catatan untuk kepentingan peneliti. Setiap data hasil reduksi, dianalisis dan ditarik kesimpulan sementara. Jika data yang disajikan belum dapat disimpulkan, data tersebut direduksi dan disesuaikan dengan data lain untuk diperbaiki. Kemudian apabila data tersebut 
telah dianggap layak untuk disimpulkan, maka ditarik kesimpulan-kesimpulan.

\section{HASIL DAN PEMBAHASAN}

Pelayanan Air Minum di PDAM TKR Kabupaten Tangerang dapat dilihat dari sudut pandang pelayanan perusahaan dengan menggunakan pendekatan stretegi perusahaan (corporate strategy), stretegi bisnis (business strategy) dan strategi fungsional (funcional strategy). Sedangkan pada aspek enterprise strategy dimana PDAM TKR Kabupaten Tangerang selayaknya harus bersungguh-sungguh bekerja dan berusaha dalam upaya memberikan pelayanan yang baik optimal kepada masyarakat sebagai pelanggan domestik belum dapat terwujud. Hal tersebut dapat kita lihat bahwa dari target Millenium Development Goals (MDGs) tahun 2015 cakupan pelayanan air minum sebesar $68,9 \%$ namun yang terealisasi di tahun 2017 hanya sebesar 30.17\%.

Secara khusus, PDAM TKR Kabupaten Tangerang untuk saat ini yang mengacu kepada Corporate Plan 2015-2019 dalam pengelolaannya masih menggunakan pendekatan strategi bisnis (business strategy) dengan langkah kebijakan sebagai berikut:

1. Meningkatkan cakupan pelayanan air minum perpipaan oleh PDAM TKR Kabupaten Tangerang;

Tabel 1: Strategi Pelayanan Air Minum PDAM TKR Kabupaten Tangerang

\begin{tabular}{ccl}
\hline No & Strategi pelayanan & \multicolumn{1}{c}{ Tujuan } \\
\hline 1 & Corporate Strategy & $\begin{array}{l}\text { Perusahaan memiliki tujuan untuk mewujudkan visi } \\
\text { dan misi organisasi serta ditunjang sinergitas antara } \\
\text { pelayanan PDAM TKR dan Pemerintah Daerah } \\
\end{array}$ \\
& & $\begin{array}{l}\text { dalam upaya mewujudkan kebijakan politik yang } \\
\text { berpihak pada masyarakat. }\end{array}$ \\
\hline 2 & Business Strategiy & PDAM TKR Kabupaten Tangerang dikelola dengan \\
\hline
\end{tabular}

2. Mewujudkan pemenuhan tarif ful cost recovery (FCR);

3. Mewujudkan pertumbuhan bisnis melalui pengembangan SPAM;

4. Menetapkan skala prioritas pengembangan SPAM; dan

5. Mencari alternatif sumber pendanaan investasi pengembangan SPAM selain internal kas PDAM TKR Kabupaten Tangerang.

Jelas bahwa dari lima formulasi kebijakan yang dirumuskan oleh PDAM TKR Kabupaten Tangerang untuk tahun 2015-2019 merupakan seperangkat kebijakan yang berorientasi pada bisnis yang menekankan minimalisir kerugian dan meningkatkan keuntungan (profit) bagi perusahaan. Hal tersebut berdampak pada kualitas layanan kepada pelanggan domestik yaitu masyarakat Kabupaten tangerang itu sendiri, dimana sampai awal tahun 2015 pelanggan domestik yang terlayani hanya mencapai $11,23 \%$ (367.200 jiwa) dari total penduduk Kabupaten Tangerang yang jumlahnya mencapai 3.270.707 jiwa.

a. Sistem pelayanan PDAM TKR Kabupaten Tangerang jika ditinjau oleh pisau analisa Master Strategi, maka dapat dipetakan sebagai mana tabel di bawah ini: 


\begin{tabular}{|c|c|c|}
\hline No & Strategi pelayanan & Tujuan \\
\hline & & $\begin{array}{l}\text { pendekatan strategi bisnis guna mendapatkan nilai } \\
\text { keuntungan bagi perusahaan serta meningkatkan } \\
\text { pemasukan bagi Pendapatan Asli Daerah (PAD) } \\
\text { Kabupaten Tangerang. }\end{array}$ \\
\hline 3 & Funcional Strategy & $\begin{array}{l}\text { PDAM TKR Kabupaten Tangerang dikelola dengan } \\
\text { pendekatan strategi fungsional guna } \\
\text { memaksimalkan fungsi produksi, fungsi pemasaran, } \\
\text { fungsi Sumber Daya Manusia, fungsi keuangan, } \\
\text { fungsi riset dan pengembangan. Secara khusus yang } \\
\text { harus difokuskan adalah strategi fungsional di } \\
\text { wilayah Sumber Daya Manusia supaya terwujud tata } \\
\text { kelola perusahaan secara profesional yang dapat } \\
\text { memberikan pelayanan yang optimal kepada } \\
\text { masyarakat. }\end{array}$ \\
\hline 4 & Enterprise Strategy & $\begin{array}{l}\text { PDAM TKR Kabupaten Tangerang hadir sebagai } \\
\text { satu institusi perusahaan daerah yang dapat } \\
\text { menjawab dan melayani setiap harapan dan } \\
\text { kebutuhan masyarakat, khususnya dalam upaya } \\
\text { ketersediaan air bersih layak minum dengan kualitas } \\
\text { yang baik, harga terjangkau atau murah serta } \\
\text { pelayanan yang optimal. }\end{array}$ \\
\hline
\end{tabular}

Pada prinsipnya, master strategy merupakan seperangkat strategi guna mewujudkan nilai publik (public value). Dari keempat strategi yang terhimpun dalam master strategy di atas, PDAM TKR Kabupaten Tangerang dinilai sudah cukup baik dalam mengaplikasikan corporate strategy, business strategy, dan funcional strategy yang berorientasi pada pengembangan perusahaan serta mendapatkan nilai keuntungan (profit) atas setiap bentuk kebijakan serta programprogram yang telah dikerjakan selama ini.

\section{Implementasi Corporate Strategy}

Mengacu pada prinsip Strategi Korporasi atau Corporate Strategy, Bupati sebagai Kepala Daerah memiliki kewenangan penuh di atas Direktur Utama
PDAM TKR Kabupaten Tangerang dalam mengeksekusi setiap kebijakan yang ditetukan oleh perusahaan. Pada penelitian ini, ditemukan di lapangan bahwa untuk meningkatkan pelayanan kepada masyarakat sebagai pelanggan domestik usulan PDAM TKR untuk menggratiskan beban biaya pembuatan saluran pipa baru ditolak oleh Bupati Kabupaten Tangerang dengan pertimbangan beban produksi sambungan pemasangan baru ini cukup tinggi, dikhawatirkan PDAM TKR Kabuapten tidak bisa mengcover beban biaya produksinya.

Hal tersebut mengindikasikan bahwa dalam prinsip nilai publik (public value), dukungan secara politik dari Pemerintah Daerah dalam hal ini Bupati Kabupaten Tangerang dirasa belum memihak kepada 
masyarakat dalam rangka mengakses air bersih untuk kebutuhan sehari-hari. Sudut pandang Pemerintah Daerah hanya fokus pada tujuan bisnis yang mendatangkan keuntungan semata, bukan pada aspek pelayanan publik secara baik dan optimal.

\section{Implementasi Business Strategy}

Pada penelitian ini, di lapangan ditemukan bahwa masyarakat masih mengeluhkan biaya pemasangan maupun biaya pembayaran air minum dari PDAM TKR Kabupaten Tangerang yang dinilai sangat mahal untuk setiap bulannya. Hal tersebut diakui oleh HS yang berprofesi sebagai buruh pabrik yang pendapatan per bulannya hanya dua juta. Ia menilai, ketimbang pendapatannya itu digunakan untuk membayar air minum dari PDAM TKR Kabupaten Tangerang lebih baik ia alokasikan kepada kebutuhan pokok keluarga lainnya. Ia memilih menggunakan air sumur untuk keperluan sehari-harinya ketimbang harus menggunakan air yang bersumber dari PDAM TKR Kabupaten Tangerang.

Hal tersebut diperkuat dalam Survei Kepuasan Pelanggan PDAM TKR Kabupaten Tangerang tahun 2016. Dalam survei tersebut disebutkan bahwa sebanyak $33.7 \%$ responden mengatakan bahwa alasan menggunakan air bersih dari selain dari PDAM TKR Kabupaten Tangerang adalah karena memiliki kualitas yang lebih baik ketimbang dari PDAM, 21.1\% sumber air selain PDAM TKR Kabupaten Tangerang dinilai lebih murah harganya, $19.5 \%$ sumber air selain PDAM TKR Kabupaten Tangerang mudah diperoleh, 7.9\% sumber air selain PDAM TKR
Kabupaten Tangerang kontinuitasnya lebih baik, 6.8\% sumber air selain PDAM TKR Kabupaten Tangerang kuantitanya lebih baik dan sisanya sebesar $11.1 \%$ menyatakan bahwa sumber air selain daripada PDAM TKR Kabupaten Tangerang dinilai lebih hemat dan lancar.

Jadi, strategi bisnis PDAM TKR Kabupaten Tangerang belum dapat mencawab harapan dan tantangan yang hadir dari masyarakat, meliputi harga air yang murah, kualitas yang lebih baik, kuantitas lebih banyak, air mudah diperoleh dan bersifat kontinyu, serta kelancaran dan memberikan sisi kehematan bagi pelanggan khusunya masyarakat sebagai pelanggan domestik.

\section{Implementasi Funcional Strategy}

Strategi Fungsional merupakan penjabaran strategi umum yang nantinya dijalankan oleh divisi-divisi organisasi. Masing-masing divisi harus diisi oleh sumber daya manusia yang sesuai dengan bidang dan keahliannya supaya kinerjanya baik dan profesional. Salah menempatkan sumber daya manusia di divisi tertentu dapat berakibat fatal kinerja dan hasil yang akan didapat oleh organisasi atau perusahaan.

Temuan di lapangan -dalam hal sumber daya manusia (SDM) PDAM TKR Kabupaten Tangerang- terdapat SDM yang difungsikan tidak sesuai dengan bidang keahliannya. Banyak para sarjana yang ditempatkan tidak sesuai dengan bidang keahliannya, seperti sarjana ekonomi difungsikan untuk mengerjakan sesuati yang bersifat teknik. Hal tersebut merupakan sisi kelemahan dan kekurangan 
SDM di PDAM TKR Kabupaten Tangerang yang berimbas pada aspek kualitas pelayanan kepada pelanggan secara baik dan optimal.

Di samping itu, faktor lain dari lemahnya sumber daya manusia yang terdapat di PDAM TKR Kabupaten Tangerang karena rasio pendidikan dan pelatihan (diklat) kepegawaian masih tergolong rendah yaitu baru mencapai 14,73 persen dari batas ideal 80 persen. Penyebabnya adalah implementasi program kerja atas peningkatan SDM tidak dijalankan secara konsisten. Kemudian, minimnya biaya diklat juga menjadi pertimbangan lain dimana yang seharusnya 10 persen baru terealisasi 0,15 persen.

Namun demikian, untuk meningkatkan kualitas sumber daya manusia tersebut, PDAM TKR Kabupaten Tangerang telah mengembangkan beberapa program yaitu:

1. Melakukan analisa pegawai pada seluruh bagian untuk mengidentifikasi kebutuhan sumber daya manusia dan struktur organisasi perusahaan yang tepat dan profesional.

2. Menyediakan alat ukur kinerja pegawai untuk mengukur dan mengevaluasi kinerja pegawai di setiap akhir tahun.

3. Menyeimbangkan rasio jumlah pegawai dengan jumlah pelanggan.

4. Melakukan program pengembangan kemampuan pegawai melalui pelatihanpelatihan serta studi banding ke beberapa instansi terkait air minum.

5. Melakukan program penyesuaian gaji setiap tahun untuk mengapresiasi prestasi yang dicapai oleh para pegawai minimal 5 persen per tahun.

Kebijakan program tersebut dipandang penting bagi PDAM TKR Kabupaten Tangerang demi mewujudkan peningkatan kualitas para pegawai dalam melayani pelanggan secara baik dan optimal.

\section{Implementasi Enterprise Strategy}

Enterprise Strategy yang berorientasi pada pelayanan kepada masyarakat umum tentu harus diperhatikan pula oleh PDAM TKR Kabupaten Tangerang di samping dengan menggunakan pendekatan corporate strategy, busssiness strategiy, dan funcional strategy guna menjadikan perusahaan dapat meraih apa yang menjadi visi yaitu menjadi perusahaan air minum yang sehat dan senantiasa memberikan pelayanan yang terbaik kepada masyarakat, demi mewujudkan keinginannya dalam memperoleh kehidupan yang lebih baik serta di satu sisi perusahaan dapat mendapatkan keuntungan untuk memberikan kontribusi yang optimal bagi Pendapatan Asli Daerah (PAD).

Enterprise Strategy yang berorientasi pada dimesi kepuasan dan respon masyarakat meliputi lima indikator, yaitu:

1. Pelayanan yang berwujud nyata (tangible) yaitu proses pelayanan yang dilakukan oleh PDAM TKR Kabupaten Tangerang terhadap para pelanggan khususnya pelanggan domestik (masyarakat) dalam hal-hal yang bersifat konkrit atau berwujud fisik meliputi mekanisme kerja, fasilitas, 
peralatan, kinerja personel/pegawai, dan lain sebagainya.

2. Kehandalan (reliability) yaitu kemampuan PDAM TKR Kabupaten Tangerang dalam melaksanakan setiap kebijakan atau janji yang telah ditetapkan secara handal dan akurat baik menyangkut ketepatan waktu layanan, kepastian tarif, ketepatan dalam pembacaan meter air dan lain sebagainya.

3. Cepat tanggap (responsiveness) yaitu bagaimana PDAM TKR Kabupaten tangerang mampu menanggapi setiap keluhan yang datang dari para pelanggan khususnya pelanggan domestik (masyarakat) terkait pelayanan yang kurang optimal dan tidak memuaskan. Kecepat-tanggapan PDAM TKR Kabupaten Tangerang secara cepat dan tepat dalam merespon setiap keluhan merupakan suatu hal yang sangat diperlukan untuk mewujudkan tingkat kepuasan dari para pelanggan.

4. Jaminan pelayanan (assurance) yaitu kecapakan para petugas/pegawai PDAM TKR Kabupaten Tangerang dalam memberikan jaminan pelayanan dan jaminan keamanan bagi para pelanggan.

5. Empati (empathy) yaitu kemampuan PDAM TKR Kabupaten Tangerang dalam memahami dan memenuhi setiap harapan dan keinginan para pelanggan.

Secara umum, dari kelima dimensi tersebut, pelanggan menyatakan cukup puas terhadap pelayanan yang dilakukan oleh PDAM TKR Kabupaten Tangerang dengan nilai indeks kepuasan tertinggi ada pada dimensi jaminan pelayanan (assurance) yaitu dari Costumer Satisfaction Index (CSI) dengan skor 63,51 dan dari American Costumer Satisfaction Index (ACSI) dengan skor 64,82 sedangkan nilai terendah ada pada dimensi cepat tanggap (responsiveness) yaitu dari Costumer Satisfaction Index (CSI) dengan skor 60,76 dan American Costumer Satisfaction Index (ACSI) dengan skor 63,18.

Dimensi jaminan pelayanan (assurance) merupakan dimensi yang paling dominan dalam memberikan kontribusi terhadap kepuasan pelanggan, sedangkan dimensi cepat tanggap (responsiveness) dan dimensi kehandalan (reliability) merupakan dua dimensi yang dinilai masih rendah sehingga diperlukan adanya perbaikan dan peningkatan sistem layanan oleh PDAM TKR Kabupaten Tangerang secara baik dan optimal.

Kemudian, mengacu pada Laporan Akhir Survei Kepuasan Pelanggan PDAM TKR Kabupaten Tangerang tahun 2016 disebutkan bahwa ada sembilan dimensi pelayanan yang perlu untuk diberikan secara baik dan optimal oleh PDAM TKR Kabupaten Tangerang kepada pelanggan khususnya pelanggan domestik, yaitu: 1) Kualitas air; 2) Kuantitas air; 3) Kelancaran/kontinuitas air; 4) Pembacaan meter air; 5) Pelayanan pemeliharaan dan perbaikan; 6) Sistem pembayaran dan penagihan; 7) Keterjangkauan tarif; 8) Pelayanan pelanggan; dan 9) Pelayanan informasi.

Mengacu pada sembilan dimensi dalam aspek pelayanan PDAM TKR Kabupaten Tangerang, di wilayan 
Pelayanan I misalnya, dimensi pelayanan yang masih rendah sehingga perlu untuk diperbaiki dan ditingkatkan bahkan menjadi prioritas utama adalah dimensi kuantitas/tekanan/kederasan air PDAM dan dimensi pelayanan informasi. Dimensi kuantitas air PDAM tersebut merupakan dimensi yang dominan namun kurang berkontribusi terhadap tingkat kepuasan pelanggan, sehingga menjadi prioritas utama dalam perbaikan pelayanan di kemudian hari. Demikian juga dengan dimensi pelayanan pelanggan (pengaduan) dan pelayanan informasi merupakan dimensi yang kurang dominan dan kurang berkontribusi terhadap tingkat kepuasan pelanggan sehingga menjadi prioritas juga untuk dilakukan perbaikan pelayanan di Wilayah Pelayanan I.

Di Wilayah Pelayanan II, terdapat tiga dimensi pelayanan yang perlu diperbaiki dan ditingkatkan oleh perusahaan demi mendapat kepuasan para pelanggan. Dimensi pembacaan meter air PDAM, dimensi pelayanan pemeliharaan dan perbaikan serta dimensi kontinuitas/kelancaran air PDAM merupakan tiga dimensi yang memiliki predikat lemah yang tidak memberikan kontribusi atas kepuasan pelanggan sehingga perlu untuk diperbaiki dan dioptimalkan oleh perusahaan di Wilayah Pelayanan II ini di kemudian hari.

Di Wilayah Pelayanan III, dimensi pelayanan pemeliharaan dan perbaikan, dimensi sistem pembayaran dan penagihan, dimensi keterjangkauan tarif, dimensi pelayanan pelanggan (pengaduan), dan dimensi pelayanan informasi merupakan dimensi yang kurang dominan dan kurang memberikan kontribusi terhadap tingkat kepuasan pelanggan PDAM TKR Kabupaten Tangerang di Wilayah Pelayanan III sehingga perlu adanya perbaikan dan optimalisasi demi mencapai tingkat kepuasan pelanggan yang baik dan optimal di kemudian hari.

Di Wilayan Pelayanan Cabang Teluknaga, dimensi kualitas air PDAM merupakan dimensi yang kurang dominan dan kurang berkontribusi terhadap tingkat kepuasan pelanggan sehingga dinilai menjadi prioritas utama untuk dilakukan perbaikan pelayanan PDAM TKR Kabupaten Tangerang untuk daerah pelayanan Cabang Teluknaga dalam mendistribusikan kualitas air yang baik. Di Wilayan Pelayanan Cabang Tigaraksa dimensi kualitas air, dimensi pelayanan pengaduan pelanggan, dan dimensi pelayanan informasi dinilai masih sangat rendah sehingga tidak memberikan peningkatan atas kepuasan pelanggan PDAM TKR Cabang Tigaraksa.

Di Wilayan Pelayanan Cabang Serpong dimensi pembacaan meter air PDAM, dimensi pelayanan pemeliharaan dan perbaikan, dimensi sistem pembayaran dan penagihan, dimensi keterjangkauan tarif, dimensi pelayanan pengaduan, dan dimensi pelayanan informasi merupakan beberapa dimensi yang dinilai kurang dominan dan kurang berkontribusi terhadap tingkat kepuasan pelanggan atas sistem pelayanan yang diberikan oleh PDAM TKR Kabaupaten Tangerang, sehingga perlu adanya perbaikan, peningkatan dan optimalisasi peran dan 
fungsi PDAM TKR Kabaupaten Tangerang dalam mewujudkan sistem pelayanan yang baik dan optimal bagi para pelanggan yang ada di wilayan pelayanan Cabang Serpong.

\section{KESIMPULAN}

Dari hasil penelitian dan pembahasan maka dapat disimpulkan bahwa strategi pelayanan air minum yang dilaksanakan oleh Perusahaan Daerah Air Minum (PDAM) Tirta Kerta Raharja (TKR) Kabupaten Tangerang masih belum optimal, hal tersebut disebabkan oleh karena strategi yang digunakan masih dengan pendekatan strategi corporate, business, dan funcional. Perusahaan Daerah Air Minum (PDAM) Tirta Kerta Raharja (TKR) Kabupaten Tangerang tidak menyertakan enterprise strategy sebagai salah satu instrumen strategi pelengkap dari Master Strategi. Sehingga dampaknya sistem pelayanan perusahaan kepada masyarakat sebagai pelanggan domestik dinilai belum mencapai target optimal dan nilai publik (public value) yang meliputi pelayanan (service), hasil (outcomes), dan kepercayaan (Trust) pada umumnya belum mencapai target yang baik dan optimal pula.

Oleh karenanya temuan konsep baru dalam penelitian ini yakni perlu adanya penerapan enterprise strategy yang secara bersamaan diterapkan dengan corporate strategy, business strategy dan funcional strategy oleh PDAM TKR Kabupaten Tangerang untuk mewujudkan nilai publik (public value) dan sistem pelayanan air minum yang baik dan optimal kepada para pelanggan khususnya pelanggan domestik (masyarakat).
Dengan demikian, untuk mengoptimalkan pelayanan air minum oleh PDAM TKR Kabupaten Tangerang perlu segera mungkin untuk menerapkan Master Strategi yang terdiri atas strategi corporate, business, funcional dan enterprise guna menciptakan nilai publik dan sistem pelayanan yang optimal.

Pemerintah Daerah dan PDAM TKR Kabupaten Tangerang harus merancang kembali strategi kebijakan perusahaan yang berpihak pada masyarakat umum sebagai bagian dari pelanggan domestik. Strategi bisnis yang berorientasi pada keuntungan (profit) harus diimbangi dengan sistem pelayanan yang baik kepada masyarakat, sehingga masyarakat dapat merasakan nilai manfaat dari air bersih layak minum yang dikelola oleh PDAM TKR Kabupaten Tangerang dengan harga yang murah dan kualitas yang baik. Beberapa saran yang perlu untuk dilakukan oleh PDAM TKR Kabupaten Tangerang, seperti:

1. Perlu adanya komitmen dan keberanian dari para pemangku kebijakan dan leading sector dalam merumuskan kewenangan dan kebijakan program strategi PDAM TKR Kabupaten Tangerang yang berpihak pada masyarakat sebagai pelangga domestik.

2. Perlu adanya pemetaan ulang secara optimal mengenai sistem pelayanan dan distribusi air minum kepada pelanggan domestik di wilayah PDAM TKR Kabupaten Tangerang sehingga perusahaan dapat mengetahui peta wilayan mana saja yang perlu sekiranya untuk dilakukan 
peningkatan pelayanan secara merata dan optimal.

3. Perlu adanya peningkatan sistem sambungan baru pelanggan domestik dengan syarat pendaftaran yang mudah, waktu pemasangan yang relatif singkat, biaya pemasangan dan pembayaran yang terjangkau serta ragam fasilitas pembayaran yang efektif dan efisien.

4. Penguatan sistem administrasi PDAM TKR Kabupaten Tangerang sehingga sistem pelayanan kepada semua pelanggan khususnya pelanggan domestik menjadi efektif dan efisien.

5. Penguatan sistem pengawasan sehingga PDAM TKR Kabupaten Tangerang beroperasi secara akuntable, transfaran dan profesional.

6. Sumber daya manusia di bidang kepegawaian harus di sesuaikan dengan bidangnya masing-masing sesuai dengan keahlian dan pendidikannya sehingga kinerja PDAM TKR Kabupaten Tangerang berjalan secara profesional. Juga dipandang perlu untuk melakukan pelatihan kepegawaian secara berkala demi meningkatkan kualitas dan mutu dari semua pegawai PDAM TKR Kabupaten Tangerang.

\section{DAFTAR PUSTAKA}

Abidin, S.Z. (2006). Dinamika Reformasi dan Revitalisasi di Indonesia. Jakarta: Suara Bebas.

Chandler, R.C. \& Plano, J.C. (1988). The Public Administration Dictionary. California: ABC-Clio.

David, F.R. (2009). Manajemen Strategis. Jakarta: Salemba Empat.
Hidayat, L. M. (2007). Reformasi Administrasi: Kajian Komparatif Pemerintahan Tiga Presiden. Jakarta: PT. Gramedia Pustka Utama.

Higgins, JM. (1985). Strategy, New York: CBS College Publishing.

Ibrahim, A. (2008). Teori dan Konsep Pelayanan Publik Serta Implementasinya. Jakarta: Mandar Maju.

Manulang, M. (1990). Dasar-Dasar Manajemen. Jakarta: Ghalia Indonesia.

Moore, M. H. (1995). Defining Public Value. In Creating Public Value. London: Harvard University Press.

O'Flynn, J. (2007). From New Public Management to Public Value: Paradigmatic Change and Managerial Implications.The Australian Journal of Public Administration.

Purwanto, D. (2006). Komunikasi Bisnis. Edisi Ketiga. Jakarta: Penerbit Erlangga.

Quinn, M. (1990). Qualitative Evaluation \& Research Methods, California: SAGE Publications, Inc.

Rusli, B. (2014). Isu-Isu Krusial Administrasi Publik Kontemporer. Bandung: Lepsindo.

Saluhu. J, (1996). Pengambilan Keputusan Stratejik: untuk Organisasi Publik dan Organisasi Nonprofit. Jakarta: PT. Grasindo.

Shafritz, JM. \& Russel. E.W. (1997). Introducing Public Administration. New York: Longman.

Sule, ET. (2009). Pengantar Manajemen. Jakarta: Kencana Perdana Media Goup.

Sutrisno, T. \& Suciastuti, E. (2002). Teknologi Penyediaan Air Bersih. Jakarta: Rineka Cipta.

Taufiqurokhman. (2016). Manajemen Strategik, Jakarta: Fakultas Ilmu Sosial dan Ilmu Politik Universitas Prof. Dr. Moestopo Beragama

Tjiptono, F. (1997). Strategi Pemasaran. Yogyakarta: Andi Offset Yogyakarta.

Zauhar, S. (1996). Reformasi Administrasi: Konsep, Dimensi dan Strategi. Jakarta: Bumi Aksara. 